\title{
Reseña del libro: Glosario de reciclaje urbano
}

\author{
José Miguel Gómez Acosta*
}

\section{Palabras clave}

Reciclaje Urbano; Rehabilitación Energética; Sostenibilidad

\section{Review of the book: Glossary of urban recycling}

\section{Key words}

Urban Recycling; Retrofiting; Sostenibility

Una época de crisis es una buena época para el reciclaje. Reciclaje material y reciclaje de ideas. Momentos donde marcar un punto de inflexión definitivo con lo anterior y colocar lo que tenemos en las condiciones adecuadas para encarar un nuevo ciclo de vida. En este contexto surge esta obra colectiva, firmada por 50 equipos que reúne casi 70 términos relacionados con el reciclaje urbano (agrociudad, arquitectura parásita, ciudad fantasma, ciudad post-oil, condensador social, corredor ecológico, crecimiento interior, empatía urbana, ficciociudades. huella ecológica, huertos urbanos, infraciclaje, jardín vertical, pielinvernadero, sinergia sostenible. sinergia, tecnología social, topofilia urbana, vivienda transicional...).

El presente glosario permite comprender y enmarcar una serie de propuestas arquitectónicas que, dentro del imaginario colectivo, tal vez tengan su punto de partida en la plaza Léon Aucoc de Burdeos, el famoso proyecto en el que Anne Lacaton y Jean Philippe Vassal decidieron no hacer en lugar de hacer. Esa inactividad cargada de ideología asentó las bases de un movimiento arquitectónico capaz de desarrollar ideas y estrategias que permitirían comenzar a romper inercias aprendidas y modos de operar acríticos, redescu- briendo valores sobre los que construir un futuro sostenible. Ideas que parten del no hacer, y que acaban transformando lo existente sin desecharlo, buscando lo concreto, creciendo en ocasiones hacia el interior, concentrándose en la realidad presente y en las posibilidades ciertas para llegar a un fin estético y funcional no determinado de antemano. En palabras de Elisa Valero, responsable de la edición y directora del proyecto: "Tras varias décadas en las que cualquier transformación urbana se ha basado en la adición al contexto de fotogénicos objetos icónicos, emerge una cultura que trata de establecer las relaciones adecuadas entre los diversos elementos como condición sine qua non para orientar nuestros pasos hacia la sostenibilidad. El presente glosario constituye un intento de recoger y definir conceptos vinculados al reciclaje urbano surgidos (o resurgidos) en los últimos años, tratando a la vez de entender la ciudad como una estructura compleja que se distancia de la invasiva cultura del "usar y tirar" proponiendo una alternativa realista que no renuncie a la excelencia".

Este glosario, manual de referencia y consulta obligada para todos aquellos interesados en el reciclaje urbano, ha contado con el asesoramiento científico de Carlos Martí Arís, Jose María 
Ezquiaga, Jose Antonio Sosa, Xavier Monteys. Más que definiciones al uso, de conceptos cerrados, el gran valor de esta obra es establecer una red de conexiones que facilitan las pautas de relación entre distintos actores y proponen una visión amplia que, indefectiblemente, conduce a otras. Según reza en la presentación del propio libro: "No es tarea fácil construir una nueva idea del habitar más humana y más justa. No es tarea de nostálgicos sino de rebeldes, pero como dice Margueritte Yourcenar, ...todos estamos obligados, en el breve curso de nuestras vidas, a elegir entre la esperanza infatigable y la prudente falta de esperanza".

\section{Cita del artículo}

GOMEZ, J. M. Reseña del libro: Glosario de reciclaje urbano. Hábitat y Sociedad, 2012, no 5, p. 133-134. $<$ www.habitatysociedad.us.es $>$.

http://dx.doi.org/10.12795/HabitatySociedad.2012.i5.10 